\title{
Synthesis and structure of stable water-soluble phosphonium-alkanoate zwitterions derived from 1,3,5-triaza-7-phosphaadamantane
}

\author{
Antal Udvardy,* Mihály Purgel, Tímea Szarvas, Ferenc Joó, Ágnes Kathó*
}

IThis paper is dedicated to Professor Magdolna Hargittai in recognition of her outstanding achievements in inorganic and structural chemistry.

A. Udvardy, M. Purgel, F. Joó

MTA-DE Homogeneous Catalysis and Reaction Mechanisms Research Group

Debrecen 10, P.O.B. 7, H-4010 Hungary

E-mail: udvardya@unideb.hu
A. Udvardy, T. Szarvas, F. Joó, Á. Kathó
Department of Physical Chemistry, University of Debrecen
Debrecen 10, P.O.B. 7, H-4010 Hungary
E-mail: katho.agnes@science.unideb.hu 


\begin{abstract}
1,3,5-Triaza-7-phosphaadamantane (pta) was shown to form phosphonium-alkanoate zwitterions with unsaturated dicarboxylic acids in water in the absence of strong acids. Solid state structures of the phosphonium salt (1) derived from maleic or fumaric acids and that of the zwitterionic product (2) of the reaction of pta with citraconic and mesaconic acids were determined by single crystal X-ray diffraction. DFT calculations gave insight into the mechanism of the reaction, including the relative reactivity of the four dicarboxylic acids, and revealed the reasons for the lack of phosphonium salt formation by pta in strongly acidic aqueous solutions.
\end{abstract}

\title{
Keywords
}

1,3,5-triaza-7-phosphaadamantane; phosphonium salt; maleic acid; fumaric acid; zwitterion; water-soluble

\section{Introduction}

Phosphonium salts play important role in chemistry, especially as precursors of phosphorus ylides in synthesis of olefins via the Wittig-reaction [1,2]. Oxidative coupling of phosphonium salts is an other method for obtaining alkenes [3]. In most cases the required phosphonium salts are obtained from triphenylphosphane by heating it with the appropriate alkyl or benzyl halide in dry solvents [1,2,4], although one-pot Wittig reactions in water, with no isolation of the intermediate posphonium salt or the ylide, have also been reported [5-7]. The reaction of $\mathrm{PPh}_{3}$ with lactones or $\alpha, \beta$-unsaturated carboxylic acids is facilitated by addition of trifluoroacetic acid [8]. The mechanochemical reaction of $\mathrm{PPh}_{3}$ and solid alkyl halides allowed solvent-free synthesis of phosphonium salts at room temperature [9].

Aqueous organometallic catalysis receives much attention as an environment-friendly way of organic synthesis, and a large part of the catalysts contain various phosphane ligands [10]. The most well known of the latter are the monosulfonated and trisulfonated triphenylphosphanes, generally used as Na-salts ( $m$ tppms and $m$ tppts, respectively; Figure $\mathrm{S} 1)$. It has been observed that in aqueous-organic biphasic systems these tertiary phosphanes react with alkyl halides, activated olefin- as well as acetylenecarboxylic acids, or acrylonitrile 
yielding the corresponding phosphonium salts [11]. In contrast to the reaction of $\mathrm{PPh}_{3}$ and $\alpha, \beta$-unsaturated acids which is reversible in anhydrous solvents and needs addition of strong acids to drive the reaction to completion, in aqueous solution the carbanionic intermediate produced by the reaction of sulfonated phosphanes and activated olefins is protonated by $\mathrm{H}_{2} \mathrm{O}$ and no acid additive is required [11]. Similarly, aldehydes yielded 1-hydroxyalkylphosphonium salts with $m$ tppms and one of the products was characterized by single crystal X-ray diffraction [12].

Earlier we investigated the possible effect of phosphonium salt formation on the kinetics of hydrogenations of various olefincarboxylic acids catalyzed by $\left[\mathrm{RhCl}(m \mathrm{tppms})_{3}\right]$ in $0.1 \mathrm{M}$ aqueous $\mathrm{HCl}$ as solvent [13]. For comparison, $m$ tppms was titrated with the substrate olefinic acids at room temperature; both reactants were dissolved in $0.1 \mathrm{M}$ aqueous $\mathrm{HCl}$ solution. Reaction of $m$ tppms with maleic acid, leading to the corresponding phosphonium salt, was fast and complete at a 1:1 molar ratio, while with fumaric acid $25 \%$ of $m$ tppms remained unreacted under the same conditions. With crotonic acid the reaction proceeded only to a negligible extent.

The sulfonated triphenylphosphanes, $m$ tppms and $m$ tppts are water-soluble due to the presence of $-\mathrm{SO}_{3}{ }^{-}$groups. In contrast, 1,3,5-triaza-7-phosphaadamantane (pta; 1,3,5-triaza-7phosphatricyclo[3.3.1.1 $1^{3,7}$ decane, Figure S1) dissolves well in water despite having no ionic substituents. It is cheap, easy to synthetize and in contrast to most other phosphanes it is stable to air oxidation even in aqueous solution [14,15]. For these reasons it is often used as ligand in water-soluble transition metal complexes for catalytic purposes as well as for studies on possible medical uses (Ru(II)-pta complexes) [16].

From coordination chemistry viewpoint, 1,3,5-triaza-7-phosphaadamantane is a small, water-soluble, caged alkylphosphane, often compared to trimethylphosphane [17]. Conversely, it is the phosphorus analog of 1,3,5,7-tetraazaadamantane (urotropine); indeed, urotropine may serve as starting material for the synthesis of pta $[18,19]$. Among other properties, similarity of pta to urotropine is shown also by the finding that dilute aqueous acids protonate one of the nitrogens of both compounds [20], while no P-protonated pta is known. Furthermore, reaction of both urotropine and pta with alkyl halides yield $\mathrm{N}$-alkylated (azonia) products [18]. This is in contrast to the easy P-alkylation of alkyl phosphanes. In agreement with these findings, phosphonium salt formation was not observed in the reaction of olefinic acids (maleic, fumaric) and with aldehydes [21] under conditions where sulfonated triphenylphosphanes showed smooth reactions (room temperature, $0.1 \mathrm{M}$ aq. $\mathrm{HCl}$ as solvent). On this basis, pta was suggested as an innocent ligand (in comparison to sulfonated tertiary 
phosphanes) of complexes applied as catalysts in hydrogenation, hydroformylation and other catalytic reactions of activated olefins in aqueous media $[21,22]$.

A few P-alkylated products (phosphonium salts) of pta, however, are known. They can be obtained by ring-closure reaction of $\left[\mathrm{RP}\left(\mathrm{CH}_{2} \mathrm{OH}\right)_{3}\right]^{+}\left[\mathrm{R}=\mathrm{CH}_{3}\left(\mathrm{CH}_{2}\right)_{\mathrm{n}}, \mathrm{n}=0-3\right]$ with $\mathrm{NH}_{3}$ and $\mathrm{HCHO}$, and the solid state structure of 7-methyl-1,3,5-triaza-7-phosphaadamantane-7-ium tetrafluoroborate ([P-methyl-pta] $\left.\mathrm{BF}_{4}\right)$, obtained by this method, has been determined [23]. Furthermore, in the Morita-Baylis-Hillman $\alpha$-hydroxyalkylation of ethyl acrylate, catalyzed by pta, the corresponding phosphonium salt, 7-(2-carboxyethyl)-1,3,5-triaza-7phosphoniatricyclo[3.3.1.1 $\left.1^{3,7}\right]$ decane (P-(2-carboxyethyl)-pta) was isolated [24] and its solid state structure was determined [25]. To remove the apparent contradiction in the literature, we decided to reinvestigate the formation of phosphonium salts in the reaction of pta with olefindicarboxylic acids in water in the absence of strong acids. Here we report the results obtained with maleic, fumaric, citraconic and mesaconic acids, and the structures of the resulting phosphonium salts. DFT calculations have also been made to reveal some mechanistic features of the formation of these phosphonium alkanoate zwitterions.

\section{Experimental}

General.

1,3,5-Triaza-7-phosphaadamantane (pta) [19] and N-methyl-pta (triflate salt) [26] were prepared as described in the literature. All other reagents were commercially available and were used as received. Distilled and deoxygenated water was used throughout.

Progress of the reactions was followed by ${ }^{31} \mathrm{P}$ NMR measurements. The products were characterized by ${ }^{1} \mathrm{H}-,{ }^{13} \mathrm{C}$, and ${ }^{31} \mathrm{P}-\mathrm{NMR}$ as well as IR spectroscopies and by ESI-MS mass spectrometry. NMR measurements were run on a BRUKER DRX 360 spectrometer; ${ }^{1} \mathrm{H}$ - and

${ }^{13} \mathrm{C}$-NMR spectra were referenced to tetramethylsilane (TMS) or sodium 2,2-dimethyl-2silapentane-5-sulfonate (DSS) standards while for ${ }^{31} \mathrm{P}-\mathrm{NMR}$ measurements $85 \% \mathrm{H}_{3} \mathrm{PO}_{4}$ was used as reference.

ESI-MS data were collected on a BRUKER BioTOF II ESI-TOF mass spectrometer, the spectra were analyzed by the IsoPro 3.1 program.

Elemental analyses were obtained using an ElementarVario Micro (CHNS) equipment.

Synthesis of phosphonium salts.

1. Synthesis of 3-carboxy-2-(1,3,5-triaza-7-phosphoniatricyclo[3.3.1.1 3,7]dec-7-yl)propanoate (1). 
a) Reaction of pta and maleic acid in aqueous solution

In a Schlenk tube, pta $(157 \mathrm{mg}, 1.0 \mathrm{mmol})$ was dissolved in $1.5 \mathrm{~mL}$ water and cooled to $1{ }^{\circ} \mathrm{C}$. A solution of maleic acid $(117 \mathrm{mg}, 1.0 \mathrm{mmol})$ in $1.0 \mathrm{~mL}$ water was added with vigorous stirring in 5 minutes and the colourless reaction mixture was further stirred at $1^{\circ} \mathrm{C}$ for $3 \mathrm{~h}$. The solvent was removed at reduced pressure, and the product was washed with methanol $(2 \times 10$ $\mathrm{mL})$, with chloroform $(2 \times 10 \mathrm{~mL})$, finally with diethyl ether $(20 \mathrm{~mL})$ and dried. White powder; yield $203 \mathrm{mg}(74 \%)$.

The same reaction was carried out also at $50^{\circ} \mathrm{C}$. After $2 \mathrm{~h}$ stirring the reaction mixture was worked up as above. Yield of 1: $190 \mathrm{mg}(70 \%)$.

Anal. calcd. for $\mathrm{C}_{10} \mathrm{H}_{16} \mathrm{PN}_{3} \mathrm{O}_{4}(\mathrm{M}=273.20)$ : C, 43.96; H, 5.90; N, 15.38\%. Found: $\mathrm{C}, 43.87$; H, 5.97; N, 15.33\%.

ESI-MS(+) for $\mathrm{C}_{10} \mathrm{H}_{17} \mathrm{~N}_{3} \mathrm{O}_{4} \mathrm{P}=[\mathrm{MH}]^{+}$calculated $\mathrm{m} / z=274.095$. Observed (in $\mathrm{H}_{2} \mathrm{O}$ ) $\mathrm{m} / z=$ 274.092. $\mathrm{C}_{10} \mathrm{H}_{16} \mathrm{~N}_{3} \mathrm{NaO}_{4} \mathrm{P}=[\mathrm{MNa}]^{+}$calculated $m / z=296.077$. Observed $\left(\right.$ in $\left.\mathrm{H}_{2} \mathrm{O}\right) \mathrm{m} / z=$ 296.074 .

${ }^{1} \mathrm{H}$ NMR $\left(360 \mathrm{MHz}, \mathrm{D}_{2} \mathrm{O}, 25^{\circ} \mathrm{C}\right) \delta 4.34-4.73\left(m, 13 \mathrm{H}, \mathrm{PCH}, \mathrm{PCH}_{2} \mathrm{~N}\right.$ and $\left.\mathrm{NCH}_{2} \mathrm{~N}\right) 2.58-3.26$ ( $\left.m, 2 \mathrm{H}, \mathrm{CHCH}_{2} \mathrm{COOH}\right) \mathrm{ppm}$.

${ }^{13} \mathrm{C}\left\{{ }^{1} \mathrm{H}\right\} \mathrm{NMR}\left(90 \mathrm{MHz}, \mathrm{D}_{2} \mathrm{O}, 25{ }^{\circ} \mathrm{C}\right) \delta 175.78\left(s, C \mathrm{OO}^{-}\right), 169.77(s, C \mathrm{OOH}), 70.69(d$, $\left.{ }^{3} J_{\mathrm{CP}}=9 \mathrm{~Hz}, \mathrm{NCH} 2 \mathrm{~N}\right), 48.83\left(d,{ }^{1} J_{\mathrm{PC}}=36 \mathrm{~Hz}, \mathrm{PCH}_{2} \mathrm{~N}\right), 40.5(m, \mathrm{PCH}), 30.51(s$, $\left.\mathrm{CHCH}_{2} \mathrm{COO}\right)$ ppm.

${ }^{31} \mathrm{P}\left\{{ }^{1} \mathrm{H}\right\}$ NMR $\left(145 \mathrm{MHz}, \mathrm{D}_{2} \mathrm{O}, 25^{\circ} \mathrm{C}\right) \delta-37.5(s) \mathrm{ppm}$.

b) Reaction of pta and maleic anhydride in aqueous solution

This reaction was carried out at $1{ }^{\circ} \mathrm{C}$ as in a) but maleic anhydride $(98 \mathrm{mg}, 1.0 \mathrm{mmol})$ was used instead of maleic acid. Yield of 1: $189 \mathrm{mg}(69 \%)$.

c) Reaction of pta and fumaric acid in aqueous solution

This reaction was carried out as in a) but using fumaric acid (117 mg, $1.0 \mathrm{mmol})$ instead of maleic acid. After $8 \mathrm{~h}$ stirring at room temperature ${ }^{31} \mathrm{P}$ NMR showed $16.4 \%$ conversion of pta into $\mathbf{1}$. The product was not isolated.

2. Synthesis of 3-carboxy-2-methyl-2-(1,3,5-triaza-7-phosphoniatricyclo[3.3.1.1 $\left.{ }^{3,7}\right]$ dec-7yl)propanoate (2). 
In a Schlenk tube, pta (500 mg, $3.18 \mathrm{mmol}$ ) was dissolved at room temperature in $3 \mathrm{~mL}$ water, then a solution of citraconic acid $(413.9 \mathrm{mg}, 3.18 \mathrm{mmol})$ in $3 \mathrm{~mL}$ acetone was added in 10 minutes with intensive stirring under argon flow. After nine months the solvent was removed at reduced pressure. The crude product was dissolved in $5 \mathrm{~mL}$ methanol then approximately $90 \%$ of the solvent was evaporated. The white crystals deposited from this solution overnight were washed with chloroform $(3 \times 10 \mathrm{~mL})$, with diethyl ether $(5 \times 10 \mathrm{~mL})$ and dried. Yield of 2: $281 \mathrm{mg}(24 \%)$.

Anal. calcd for $\mathrm{C}_{11} \mathrm{H}_{18} \mathrm{~N}_{3} \mathrm{O}_{4} \mathrm{P} \times 0.5 \mathrm{H}_{2} \mathrm{O}(\mathrm{M}=296.23)$ : $\mathrm{C}, 44.59 ; \mathrm{H}, 6.46 ; \mathrm{N}, 14.18$. Found: $\mathrm{C}$, 44.42; H, 7.14; N; $13.77 \%$.

ESI-MS(+) for $\mathrm{C}_{11} \mathrm{H}_{19} \mathrm{~N}_{3} \mathrm{O}_{4} \mathrm{P}=[\mathrm{MH}]^{+}$calculated $m / z=288.111$. Observed (in $\mathrm{H}_{2} \mathrm{O}$ ) $\mathrm{m} / z=$ 288.107. $\mathrm{C}_{11} \mathrm{H}_{18} \mathrm{~N}_{3} \mathrm{NaO}_{4} \mathrm{P}=[\mathrm{MNa}]^{+}$calculated $m / z=310.093$. Observed $\left(\right.$ in $\left.\mathrm{H}_{2} \mathrm{O}\right) \mathrm{m} / z=$ 310.084 .

${ }^{1} \mathrm{H}-\mathrm{NMR}\left(360 \mathrm{MHz}, \mathrm{D}_{2} \mathrm{O}-\mathrm{MeOH}, 25{ }^{\circ} \mathrm{C}\right) \delta$ 4.35-4.66 ( $\left.m, 12 \mathrm{H}, \mathrm{P}^{+} \mathrm{CH}_{2} \mathrm{~N}, \mathrm{NCH}_{2} \mathrm{~N}\right), 2.55-2.96$ ( $\left.m, 2 \mathrm{H}, \mathrm{CH}_{2} \mathrm{COO}^{-}\right), 1.42\left(d, J_{\mathrm{PH}}=18 \mathrm{~Hz}, 3 \mathrm{H}, \mathrm{P}^{+} \mathrm{C}-\mathrm{CH}_{3}\right)$ ppm.

${ }^{13} \mathrm{C}\left\{{ }^{1} \mathrm{H}\right\}$ NMR (90 MHz, $\left.\mathrm{D}_{2} \mathrm{O}-\mathrm{MeOH}, 25^{\circ} \mathrm{C}\right) \delta 175.07$ and $174.35\left(s, \mathrm{COOH}, \mathrm{COO}^{-}\right), 70.54$

$\left(d,{ }^{3} J_{\mathrm{CP}}=8 \mathrm{~Hz}, \mathrm{NCH}_{2} \mathrm{~N}\right), 49.11\left(d,{ }^{1} J_{\mathrm{CP}}=39 \mathrm{~Hz}, \mathrm{P}^{+} \mathrm{C}\right), 48.41\left(d,{ }^{1} J_{\mathrm{CP}}=33 \mathrm{~Hz}, \mathrm{P}^{+} C \mathrm{H}_{2} \mathrm{~N}\right), 39.51$ $\left(s, \mathrm{CH}_{2}\right), 18.86\left(s, \mathrm{CCH}_{3}\right) \mathrm{ppm}$.

${ }^{31} \mathrm{P}\left\{{ }^{1} \mathrm{H}\right\}$ NMR $\left(145 \mathrm{MHz}, \mathrm{D}_{2} \mathrm{O}-\mathrm{MeOH}, 25{ }^{\circ} \mathrm{C}\right) \delta-35.6(s) \mathrm{ppm}$.

${ }^{31} \mathrm{P}\left\{{ }^{1} \mathrm{H}\right\}$ NMR $\left(145 \mathrm{MHz}, \mathrm{D}_{2} \mathrm{O}, 25{ }^{\circ} \mathrm{C}\right) \delta-34.2(s) \mathrm{ppm}$.

\section{Single crystal X-ray diffraction measurements.}

$\mathrm{X}$-ray quality crystals were obtained by layering 2-propanol on concentrated aqueous solutions of 1 and 2. Diffraction measurements were made by Dr. Attila Bényei (University of Debrecen) on a Bruker-Nonius MACH3 four-circle diffractometer equipped with a point

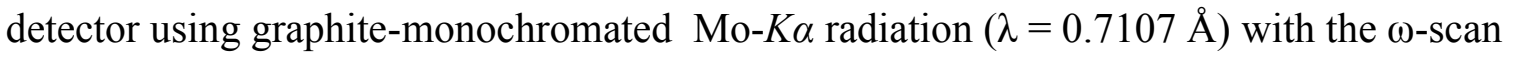
method. Structures were solved by the SIR-92 program [27] and refined by full-matrix leastsquares method on $F^{2}$. Non-hydrogen atoms were refined with anisotropic thermal parameters using the SHELXL-97 package [28]. Publication material was prepared using the WINGX-97 suite [29] and the Mercury program. 
Table 1. Crystallographic data and structure refinement results for $\mathbf{1}$ and $\mathbf{2 .}$

\begin{tabular}{|c|c|c|}
\hline & 1 & 2 \\
\hline empirical formula & $\mathrm{C}_{10} \mathrm{H}_{16} \mathrm{~N}_{3} \mathrm{O}_{4} \mathrm{P}$ & $\mathrm{C}_{11} \mathrm{H}_{20} \mathrm{~N}_{3} \mathrm{O}_{4} \mathrm{P} \times \mathrm{H}_{2} \mathrm{O}$ \\
\hline formula weight & 273.23 & 305.27 \\
\hline crystal size $[\mathrm{mm}]$ & $0.32 \times 0.21 \times 0.20$ & $0.43 \times 0.3 \times 0.25$ \\
\hline $\mathrm{T}[\mathrm{K}]$ & $293(2)$ & $293(2)$ \\
\hline$\lambda[\AA]$ & 0.71073 & 0.71073 \\
\hline crystal system & Orthorhombic & Monoclinic \\
\hline space group & $P b c a$ & $P 2{ }_{1} / n$ \\
\hline color, shape & prism/colourless & block/colourless \\
\hline $\mathrm{a}[\AA]$ & $10.133(1)$ & $6.465(2)$ \\
\hline $\mathrm{b}[\AA]$ & $12.823(4)$ & $11.700(3)$ \\
\hline c $[\AA]$ & $18.114(7)$ & $17.434(6)$ \\
\hline$\alpha\left[^{\circ}\right]$ & 90 & 90 \\
\hline$\beta\left[^{\circ}\right]$ & 90 & $93.39(3)$ \\
\hline$\gamma\left[{ }^{\circ}\right]$ & 90 & 90 \\
\hline $\mathrm{V}\left[\AA^{3}\right]$ & $2353.7(12)$ & $1316.4(7)$ \\
\hline Z & 8 & 4 \\
\hline$\rho$ calcd $\left[\mathrm{g} \mathrm{cm}^{-3}\right]$ & 1.542 & 1.54 \\
\hline$\mu\left[\mathrm{mm}^{-1}\right]$ & 0.25 & 0.23 \\
\hline$\Theta$ range $\left[{ }^{\circ}\right]$ & $2.8-25.3$ & $2.9-25.3$ \\
\hline total reflns. & 2579 & 2654 \\
\hline unique reflns. & 2085 & 2654 \\
\hline data/restraints/parameters & $2085 / 1 / 168$ & $2654 / 4 / 192$ \\
\hline final $\mathrm{R}$ indices $[I>2 \sigma(I)]$ & 0.097 & 0.088 \\
\hline $\mathrm{R}$ indices (all data) & 0.195 & 0.239 \\
\hline GOF & 0.98 & 1.02 \\
\hline$\Delta \rho_{\max } / \Delta \rho_{\min }\left[\mathrm{e} \AA^{-3}\right]$ & $0.36 /-0.37$ & $0.62 /-0.48$ \\
\hline
\end{tabular}

\section{DFT calculations.}

DFT calculations were performed with M06 [30] hybrid functional and with the 6-311+G(d,p) triple- $\zeta$ Pople-type basis sets with one set of diffuse and polarization functions. [31]. For the calculations the Gaussian 09 software package have been used [32]. Geometry optimizations were carried out using Gaussian 09's default Integral Equation Formalism variant (IEFPCM) PCM model $[33,34]$. Transition state was optimized by means of the synchronous transitguided quasi-Newton method $[35,36]$. The lack of imaginary frequencies in vibrational spectral calculations were taken to verify that the calculated stationary points on the potential energy surfaces (PES) represented true minima as opposed to transition states (TS). The relative energies are Gibbs free energies obtained by frequency analysis at $298 \mathrm{~K}$. NBO 
analysis was also performed to determine the donor-acceptor interactions inside the reactants and the products.

\section{Results and discussion}

Synthesis and general characterization of $\mathbf{1}$ and $\mathbf{2}$

${ }^{31} \mathrm{P}-\mathrm{NMR}$ spectroscopy revealed a spontaneous reaction of pta and olefindicarboxylic acids in aqueous solution at $1{ }^{\circ} \mathrm{C}$. In the ${ }^{31} \mathrm{P}-\mathrm{NMR}$ spectrum of a solution containing equivalent amounts of pta and maleic acid a new signal was detected at $\delta=-37.5$ ppm already after 30 min, the intensity of which gradually increased in time accompanied with the intensity decrease of the signal at $\delta=-90.1 \mathrm{ppm}$ characteristic for the starting material (Figure 1). In three hours, this latter signal completely disappeared and only the ${ }^{1} \mathrm{H}$ resonance of the new compound (together with that of $3 \%$ pta oxide at $\delta=-2.2 \mathrm{ppm}$ ) was detected. Similar observations were made when maleic acid was replaced by maleic anhydride (Scheme 1).

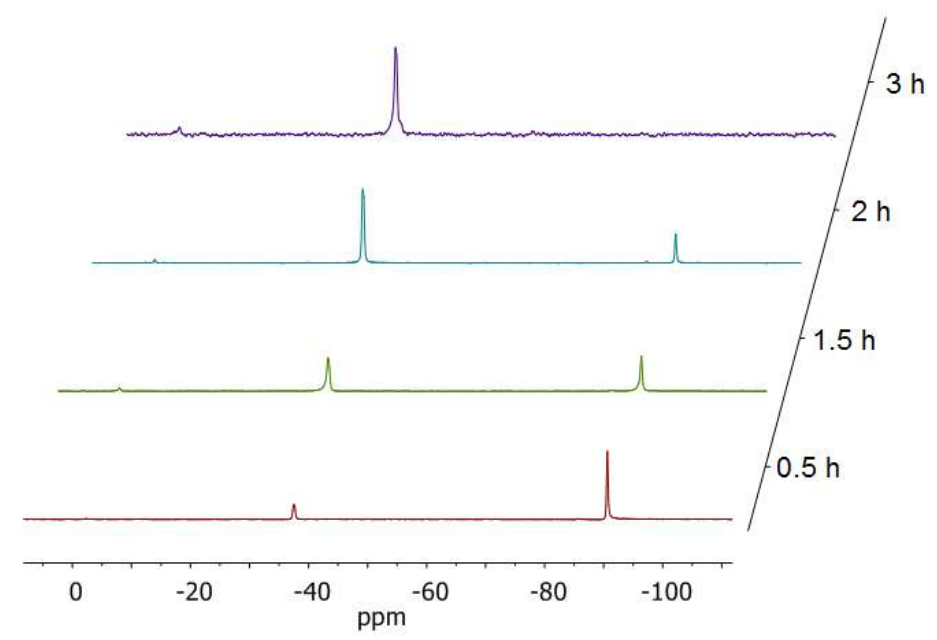

Figure 1. ${ }^{31} \mathrm{P}-\mathrm{NMR}$ spectra of the aqueous reaction mixtures containing equivalent amounts of pta and maleic acid as a function of time. Conditions: pta $(157 \mathrm{mg}, 1.0 \mathrm{mmol})$ and maleic acid $(117 \mathrm{mg}, 1.0 \mathrm{mmol})$ in $2.5 \mathrm{~mL}$ water, $\mathrm{T}=1{ }^{\circ} \mathrm{C}$. 


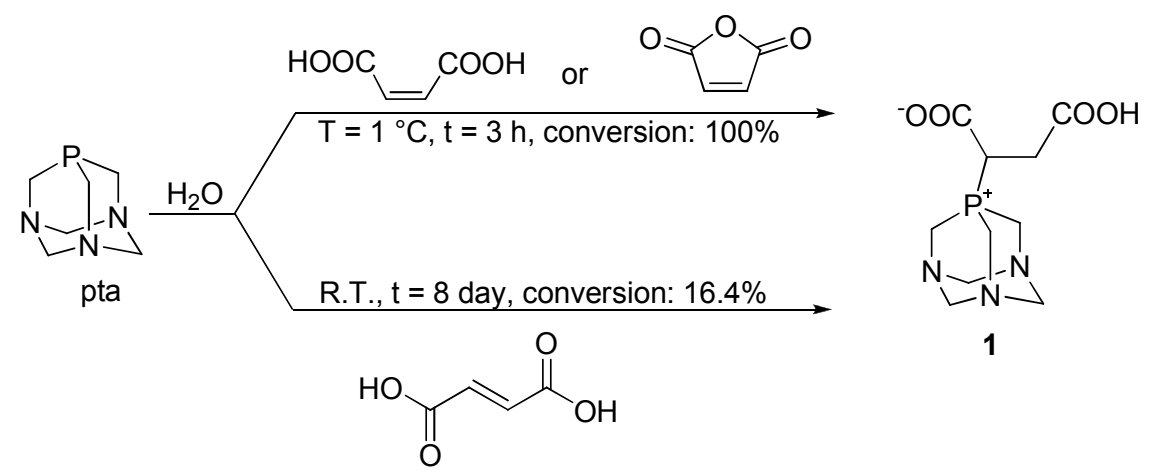

Scheme 1. Formation of phosphonium alkanoate zwitterion 1 from pta and maleic or fumaric acids.

In case of maleic acid, an increase of the reaction temperature to $50^{\circ} \mathrm{C}$ resulted in formation of $64 \%$ phosphonium salt and $4 \%$ of phosphane oxide in $30 \mathrm{~min}$, and the reaction was complete in 2 hours ( $95 \% 1$ and 5\% phosphane oxide). The oxide could be removed by washing the crude products with methanol and chloroform.

In the product, one of the carboxyl functions is protonated, while the other is deprotonated and serves as counter ion to the positively charged phosphorus. The suggested composition of $\mathbf{1}$ (Scheme 1) is in agreement with the data of elemental analysis and with the ESI-MS spectra. In the positive mode ESI-MS spectra the most intensive line at $m / z=296.074$ belongs to the $\mathrm{Na}^{+}$-associated molecular ion, while the next most intense at $m / z=274.092$ to the protonated molecular ion. Upon layering 2-propanol onto an aqueous solution of $\mathbf{1}$, good quality crystals were obtained and the solid state structure of $\mathbf{1}$ was determined by single crystal X-ray diffraction. The structure (see later) agrees well with formulation of $\mathbf{1}$ as a zwitterionic compound.

Interaction of pta with fumaric acid also yields $\mathbf{1}$, however, the reaction is slow. Under the same conditions as with maleic acid $\left(\mathrm{T}=1{ }^{\circ} \mathrm{C}, \mathrm{t}=3 \mathrm{~h}\right)$ no reaction was observed. In contrast, at room temperature $8.8 \%$ conversion to 1 was detected after 1 day, and that increased to $16.4 \%$ after 8 days (accompanied by $4.7 \%$ of pta oxide). Increasing the temperature to $50^{\circ} \mathrm{C}$ resulted in formation of an $56 \%$ yield of 1 , however this was accompanied by extensive oxidation of pta (26\% pta oxide).

The reactions of 2-methylmaleic (citraconic) and 2-methylfumaric (mesaconic) acids with pta were found very slow. When a solution of citraconic acid was added to an aqueous solution of pta and left to react for 9 months, phosphonium salt 2 was formed with $44 \%$ 
conversion of pta (Scheme 2). Under the same conditions, mesaconic acid and pta yielded 2 with $8.5 \%$ conversion (Scheme 2 ; determined by ${ }^{31} \mathrm{P}$ NMR spectroscopy).

Similar to 1, the elemental analysis and ESI-MS data are in agreement with the formulation of $\mathbf{2}$ as a zwitterion. In the positive mode ESI-MS spectra the most intensive line at $m / z=288.107$ belongs to the protonated molecular ion, while the next most intense at $m / z=310.084$ to the $\mathrm{Na}^{+}$-associated molecular ion.

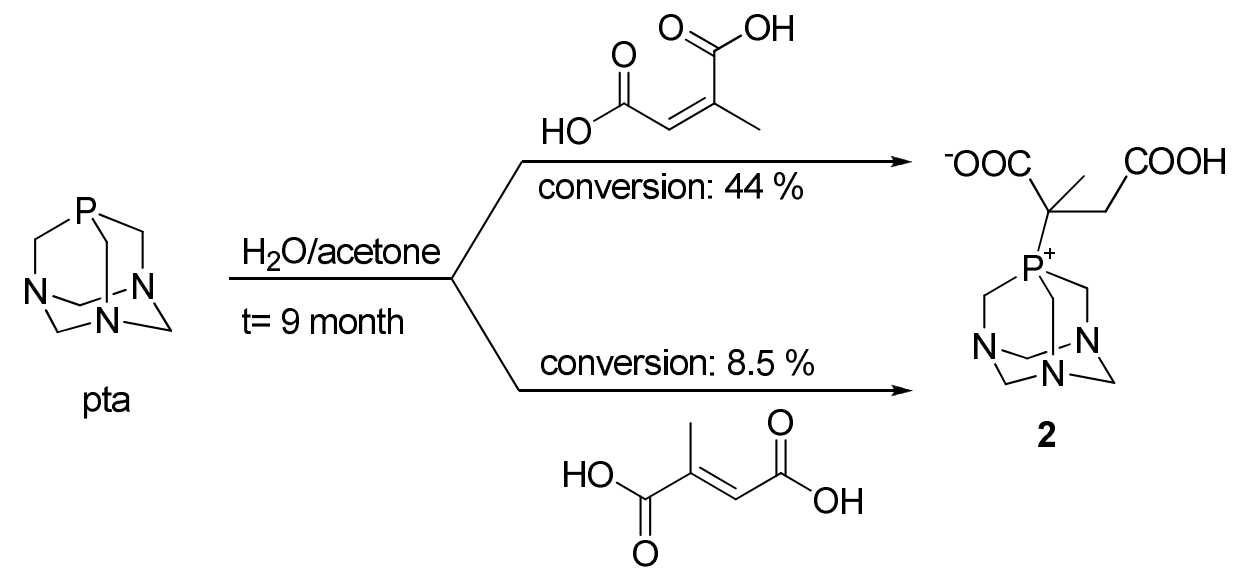

Scheme 2. Formation of phosphonium alkanoate zwitterion 2 from pta and citraconic or mesaconic acids.

Crystals of 2 suitable for single crystal X-ray diffraction measurements were also isolated by layering 2-propanol on top of concentrated aqueous solutions of 2 . The solid state structure of $\mathbf{2}$ together with that of $\mathbf{1}$ is discussed later.

For comparison, reactions of N-methyl-pta with maleic and fumaric acids were also attempted. In an NMR tube $10 \mathrm{mg}(0.032 \mathrm{mmol})$ (pta-Me) $\mathrm{CF}_{3} \mathrm{SO}_{3}$ was reacted with equivalent amounts of maleic and fumaric acids as well as with maleic anhydride first at $1{ }^{\circ} \mathrm{C}$ for $4 \mathrm{~h}$ and then at $50^{\circ} \mathrm{C}$ for $4 \mathrm{~h}$ in $0.5 \mathrm{~mL}$ deoxygenated $\mathrm{D}_{2} \mathrm{O}$. However, formation of methylated phosphonium salts was not observed in either case, the ${ }^{31} \mathrm{P}$ NMR spectra displayed only a signal at $\delta=-84.9 \mathrm{ppm}$ characteristic for the (pta-Me) $)^{+}$cation.

$\mathbf{1}$ and $\mathbf{2}$ are stable to air oxidation. Their aqueous solutions were kept at $80^{\circ} \mathrm{C}$ for 6 hours with no change in the ${ }^{31} \mathrm{P}-\mathrm{NMR}$ spectrum, and similarly, no oxidation took place during the same reaction time in their solutions made with aqueous $5 \% \mathrm{H}_{2} \mathrm{O}_{2}$. In $0.1 \mathrm{M} \mathrm{NaOH}$ solutions under air no pta-oxide was detected, however when 1 was dissolved in $1.0 \mathrm{M}$ aqueous $\mathrm{NaOH}$, pta was oxidized gradually with conversions of $18 \%$ in 1 h, $46 \%$ in 4 h, and $100 \%$ in $6 \mathrm{~h}$. 


\section{Solid state structures of 1 and 2}

Solid state structures of $\mathbf{1}$ and $\mathbf{2}$ were determined by single cystal X-ray diffraction; ORTEP diagrams are shown of Figure 2.

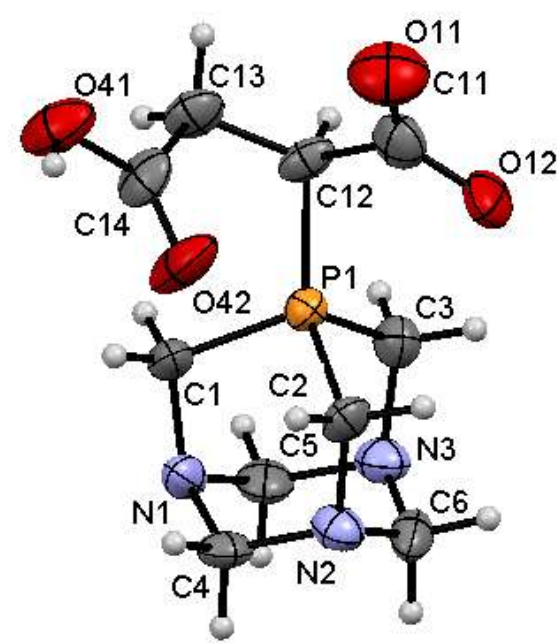

1

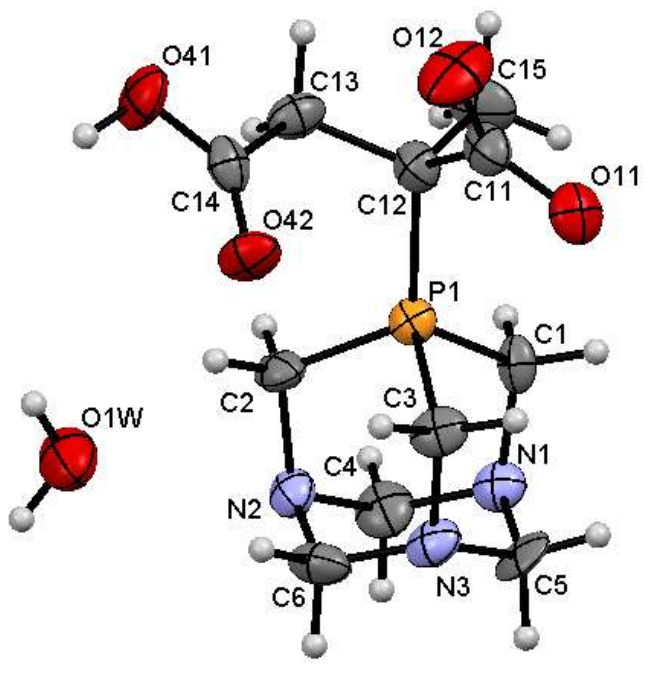

2

Figure 2. ORTEP views of $\mathbf{1}$ and $\mathbf{2}$ at the $50 \%$ probability level with atom numbering. Selected bond lengths and angles are shown in Table 2.

In both compounds the carboxylic functions closer to the positively charged phosphorus are deprotonated, while the other remains protonated. In the known P-alkylated pta derivatives (P-methyl-pta [23] and P-(2-carboxyethyl-pta [25]) the C1-P, C2-P and C3-P bond distances are significantly shorter than in pta [37]. The same is observed in case of $\mathbf{1}$ and $\mathbf{2}$; in general, the C1-, C2-, C3-P bond distances are closer to those in P-methyl-pta than to those in P-(2carboxyethyl)-pta (Table 2). The C12-P distances in $\mathbf{1}$ and $\mathbf{2}$ are larger than in P-methyl-pta and close to that in P-(2-carboxyethyl)-pta, and this bond is longer in $\mathbf{1}$ than in 2; both observations are in agreement with the reduced electron density on $\mathrm{C} 12$ due to carboxylate substitution. The bond distance date refer to $\mathrm{P}^{+}-\mathrm{C}\left(\mathrm{sp}^{3}\right)$ type bonds. The $\mathrm{C}=\mathrm{C}$ bond distances in maleic acid are $1.45 \AA$ [38]; for the phosphonium salts formed with pta the C12-C13 distances were determined as $1.499(10) \AA$ (1) and 1.508(12) $\AA$ (2). This again shows the presence of $\mathrm{C}\left(\mathrm{sp}^{3}\right)-\mathrm{C}\left(\mathrm{sp}^{3}\right)$ single bonds in these compounds. 
Table 2. Selected bond distances and bond angles in 1, 2, pta [37], [P-methyl-pta]BF 4 [23] and P-(2-carboxyethyl)-pta [25].

\begin{tabular}{|c|c|c|c|c|c|}
\hline & $(\mathbf{1})$ & $\mathbf{( 2 )}$ & pta & $\begin{array}{c}{[\text { P-methyl-pta }]} \\
\mathrm{BF}_{4}{ }^{\text {a) }}\end{array}$ & $\begin{array}{c}\text { P-(2-carboxyethyl)- } \\
\mathrm{pta}^{\text {a) }}\end{array}$ \\
\hline $\begin{array}{c}\text { Bond } \\
\text { distance } \\
(\AA)\end{array}$ & & & & & \\
\hline C1-P & $1.819(9)$ & $1.822(8)$ & $1.8561(5)$ & $1.8122(3)$ & $1.832(2)$ \\
\hline C2-P & $1.810(9)$ & $1.789(8)$ & $1.8561(4)$ & $1.8119(3)$ & $1.831(2)$ \\
\hline C3-P & $1.819(9)$ & $1.811(8)$ & $1.8561(5)$ & $1.8088(3)$ & $1.824(2)$ \\
\hline C12-P & $1.826(8)$ & $1.818(9)$ & N/A & $1.7721(2)$ & $1.807(2)$ \\
\hline C12-C13 & $1.499(10)$ & $1.508(12)$ & N/A & N/A & $1.518(2)$ \\
\hline C12-C15 & N/A & $1.532(12)$ & N/A & N/A & N/A \\
\hline $\begin{array}{c}\text { Bond angles } \\
\left({ }^{\circ}\right)\end{array}$ & & & & & $99.61(9)$ \\
\hline C1-P-C2 & $101.6(4)$ & $100.0(4)$ & 96.06 & 101.5 & $100.14(9)$ \\
\hline C1-P-C3 & $102.3(4)$ & $100.9(4)$ & 96.06 & 101.8 & $102.47(9)$ \\
\hline C2-P-C3 & $100.4(4)$ & $102.2(4)$ & 96.06 & 103.2 & $121.26(9)$ \\
\hline C1-P-C12 & $113.8(4)$ & $113.2(4)$ & N/A & 115.9 & $105.91(9)$ \\
\hline C2-P-C12 & $112.6(4)$ & $115.1(4)$ & N/A & 115.0 & $121.26(9)$ \\
\hline C3-P-C12 & $123.3(4)$ & $122.3(4)$ & N/A & 117.3 & \\
\hline
\end{tabular}

a) For the numbering scheme of these compounds see Figure S2.

In contrast to the equal and relatively small C1-P-C2, C1-P-C3, and C2-P-C3 bond angles in pta $\left(96.06^{\circ}\right)$, the same angles in $\mathbf{1}$ and $\mathbf{2}$ are larger and fall into the range of 112.6-123.3 ${ }^{\circ}$ Of these bond angles, one is considerably larger $\left(122.3-123.3^{\circ}\right)$ than the other two $\left(112.5-115.1^{\circ}\right)$ and consequently the $\mathrm{C} 12-\mathrm{P}$ bond is tilted relative to the same $\mathrm{P}-\mathrm{C}$ bond in the highly symmetric P-methyl-pta (Figure S3). Other bond distance and angle data of the phosphonium salts $\mathbf{1}$ and $\mathbf{2}$ are in good agreement with the corresponding data of pta and this can be explained by the utmost rigidity of the adamantane-like cage structure of pta.

The crystals of $\mathbf{1}$ and $\mathbf{2}$ show layered structures built up by layers of the apolar pta moieties as well as by those of the polar carboxylic acid residues.

An important finding is in that in the crystals of 1 there is a strong hydrogen bond interaction between the $\mathrm{C} 3$ carbon and the $\mathrm{O} 42$ oxygen of the closer carboxylate group $\left(\mathrm{d}_{\mathrm{C} 3-\mathrm{H} . .042}=2.941(11) \AA\right)$. In addition, strong hydrogen bonds are formed between the protonated and deprotonated carboxylic/carboxylate groups $\left(\mathrm{d}_{\mathrm{O} 41-\mathrm{H} . . \mathrm{O} 12}=2.480(10) \AA\right)$. This 
leads to formation of molecular chains which are packed into layers within the crystal. Weak $\mathrm{H}-$ bonding interactions can be found between $\mathrm{O} 11-\mathrm{C} 2$, O11-C12 and $\mathrm{O} 12-\mathrm{C} 3$, too $\left(\mathrm{d}_{\mathrm{C} 2-\mathrm{H} . . \mathrm{O} 11}=3.168 \AA, \mathrm{d}_{\mathrm{C} 12-\mathrm{H} . . \mathrm{O} 11}=3.194(12) \AA\right.$, and $\left.\mathrm{d}_{\mathrm{C} 3-\mathrm{H} . . \mathrm{O} 12}=3.104(11) \AA\right)$. The H-bond network and the layered structure of the crystals of $\mathbf{1}$ are shown on Figure 3.

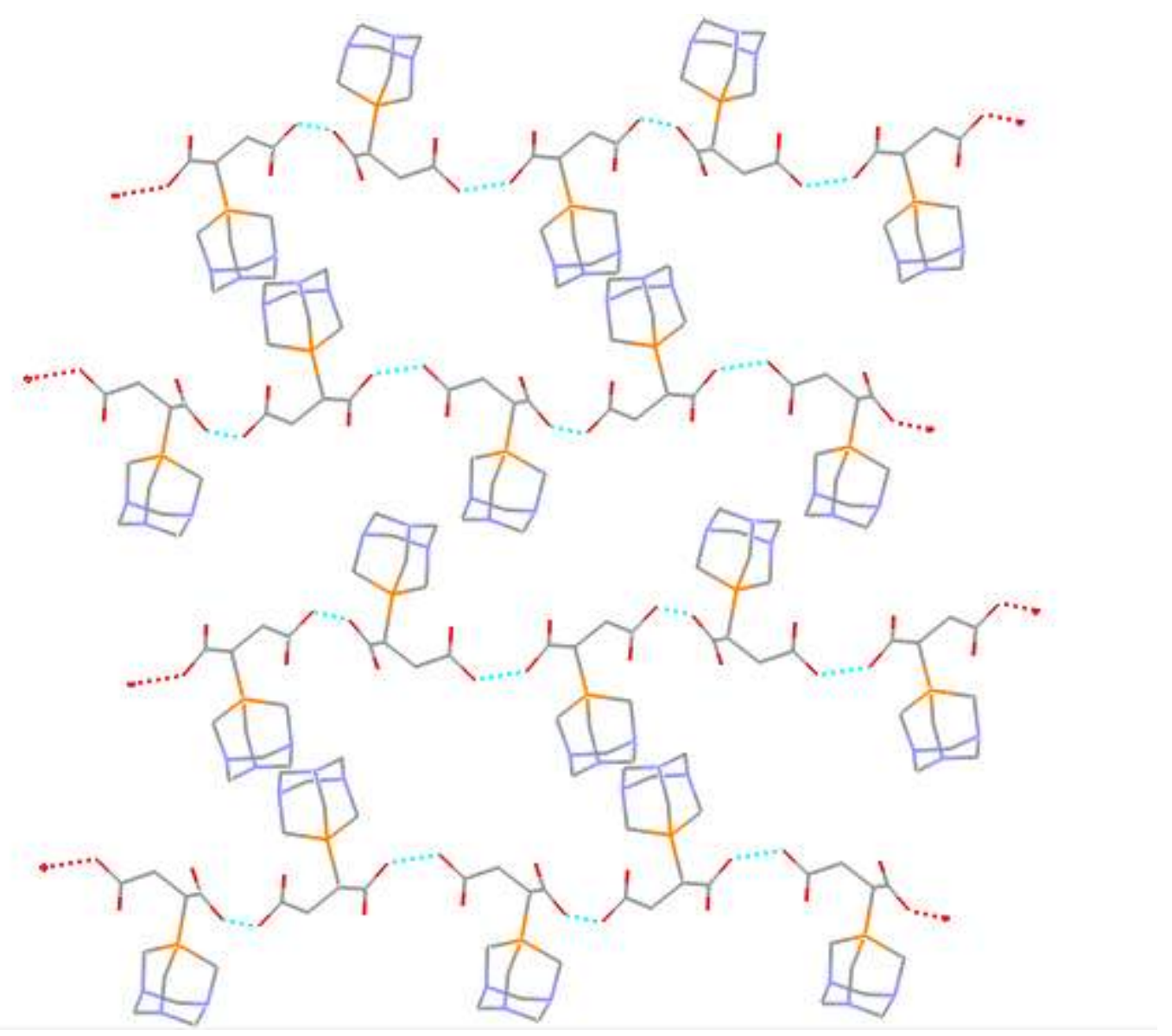

Figure 3. H-bond network and layered structure of crystals of $\mathbf{1}$.

Crystal structure of $\mathbf{2}$ is also influenced by the presence of lattice water molecules. Similar to the case of $\mathbf{1}$, strong hydrogen bonds are formed between the protonated and deprotonated carboxylic/carboxylate groups $\left(\mathrm{d}_{\mathrm{O} 41-\mathrm{H} . \mathrm{OO} 12}=2.512(10) \AA\right)$. There are strong hydrogen bonds also between the O12 oxygen and the O1W lattice water oxygen $\left(\mathrm{d}_{\mathrm{O} 1 \mathrm{~W}-\mathrm{H} . . \mathrm{O} 12}=2.798(10) \AA\right)$. A somewhat weaker interaction is detected between the $\mathrm{N} 3$ nitrogen of pta and $\mathrm{O} 1 \mathrm{~W}\left(\mathrm{~d}_{\mathrm{O} 41-}\right.$ H..N3 $=2.970(10) \AA$ ). For comparison, it is mentioned here that crystals of P-(2-carboxyethyl)pta [25] also contain lattice water molecules and these participate in the hydrogen bond network by establishing an $\mathrm{H}$-bond $(\mathrm{d}=2.942 \AA)$ to one of the nitrogen atoms of the pta 
moiety. Such an interaction is obviously missing in the crystal of $\mathbf{1}$ containing no lattice water. An even weaker hydrogen bonding is observed between $\mathrm{O} 11$ and $\mathrm{C} 3\left(\mathrm{~d}_{\mathrm{C} 3-}\right.$ H..O11 $=3.001(11) \AA)$, however, note that this distance is shorter than the corresponding one in 1. The H-bond network and the layered structure of the crystals of $\mathbf{2}$ are shown on Figure 4.

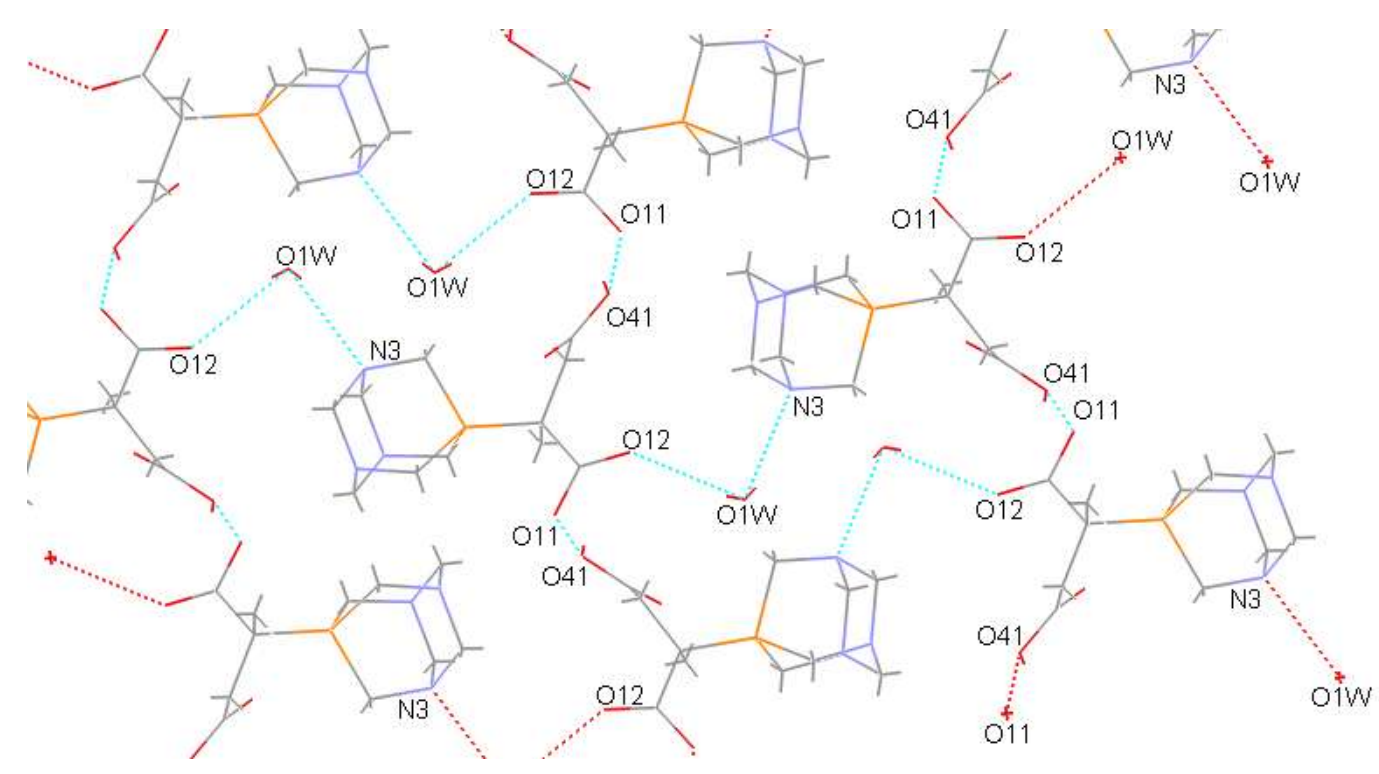

Figure 4. H-bond network and the layered structure of the crystals of 2.

\section{Theoretical investigations}

In order to get an insight into the formation as well as into the structural and energetical properties of phosphonium salts from pta and unsaturated dicarboxylic acids quantum chemical (DFT) calculations were carried out. The structure of pta with atom numbering is shown on Figure 5.

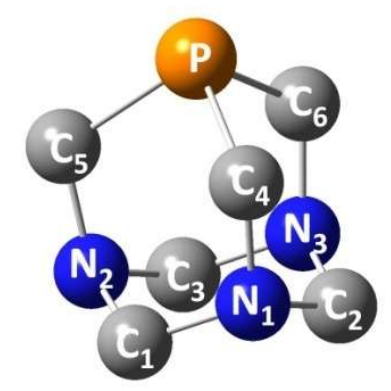

Figure 5. Structure of pta with atom numbering

NBO calculations revealed significant donor-acceptor interactions within the pta molecule. Namely, the lone electron pairs of the nitrogens $(\mathrm{N})$ are donated to the unoccupied $\mathrm{P}-\mathrm{C}$ and 
$\mathrm{C}-\mathrm{N}$ bonds leading to increased stability of the molecule. It is known that on the action of strong acids (such as $\mathrm{HCl}$ ) pta is protonated on one of its nitrogen atoms [20]. According to the calculations, protonation of pta on $\mathrm{N}_{1}$ results in distortion in the electron density distribution and the donor-acceptor interactions of the protonated nitrogen disappear (Table 3).

Table 3. Selected donor-acceptor interactions of pta and its derivatives.

\begin{tabular}{|c|c|c|c|}
\hline molecule & Donor NBO & Acceptor NBO & $\Delta \mathrm{E}(\mathrm{kcal} / \mathrm{mol})$ \\
\hline pta & $\operatorname{LP}\left(\mathrm{N}_{1}\right)$ & $\mathrm{BD}^{*}\left(\mathrm{C}_{1}-\mathrm{N}_{2}\right)$ & 9.8 \\
\hline pta & $\operatorname{LP}\left(\mathrm{N}_{1}\right)$ & $\mathrm{BD}^{*}\left(\mathrm{C}_{2}-\mathrm{N}_{3}\right)$ & 9.8 \\
\hline pta & $\operatorname{LP}\left(\mathrm{N}_{1}\right)$ & $\mathrm{BD}^{*}\left(\mathrm{P}-\mathrm{C}_{4}\right)$ & 10.0 \\
\hline pta & $\mathrm{LP}\left(\mathrm{N}_{2}\right)$ & $\mathrm{BD}^{*}\left(\mathrm{C}_{1}-\mathrm{N}_{1}\right)$ & 9.8 \\
\hline pta & $\operatorname{LP}\left(\mathrm{N}_{2}\right)$ & $\mathrm{BD}^{*}\left(\mathrm{C}_{3}-\mathrm{N}_{3}\right)$ & 9.8 \\
\hline pta & $\mathrm{LP}\left(\mathrm{N}_{2}\right)$ & $\mathrm{BD}^{*}\left(\mathrm{P}-\mathrm{C}_{5}\right)$ & 10.0 \\
\hline pta & $\operatorname{LP}\left(\mathrm{N}_{3}\right)$ & $\mathrm{BD}^{*}\left(\mathrm{C}_{2}-\mathrm{N}_{1}\right)$ & 9.8 \\
\hline pta & $\operatorname{LP}\left(\mathrm{N}_{3}\right)$ & $\mathrm{BD}^{*}\left(\mathrm{C}_{3}-\mathrm{N}_{2}\right)$ & 9.8 \\
\hline pta & $\operatorname{LP}\left(\mathrm{N}_{3}\right)$ & $\mathrm{BD}^{*}\left(\mathrm{P}-\mathrm{C}_{6}\right)$ & 10.0 \\
\hline $\operatorname{pta}\left(\mathrm{N}_{1}\right) \mathrm{H}^{+}$ & $\mathrm{LP}\left(\mathrm{N}_{2}\right)$ & $\mathrm{BD}^{*}\left(\mathrm{C}_{1}-\mathrm{N}_{1}\right)$ & 16.1 \\
\hline $\operatorname{pta}\left(\mathrm{N}_{1}\right) \mathrm{H}^{+}$ & $\mathrm{LP}\left(\mathrm{N}_{2}\right)$ & $\mathrm{BD}^{*}\left(\mathrm{C}_{3}-\mathrm{N}_{3}\right)$ & 9.6 \\
\hline $\operatorname{pta}\left(\mathrm{N}_{1}\right) \mathrm{H}^{+}$ & $\mathrm{LP}\left(\mathrm{N}_{2}\right)$ & $\mathrm{BD}^{*}\left(\mathrm{P}-\mathrm{C}_{5}\right)$ & 9.3 \\
\hline $\operatorname{pta}\left(\mathrm{N}_{1}\right) \mathrm{H}^{+}$ & $\operatorname{LP}\left(\mathrm{N}_{3}\right)$ & $\mathrm{BD}^{*}\left(\mathrm{C}_{2}-\mathrm{N}_{1}\right)$ & 16.1 \\
\hline $\operatorname{pta}\left(\mathrm{N}_{1}\right) \mathrm{H}^{+}$ & $\operatorname{LP}\left(\mathrm{N}_{3}\right)$ & $\mathrm{BD}^{*}\left(\mathrm{C}_{3}-\mathrm{N}_{2}\right)$ & 9.6 \\
\hline $\operatorname{pta}\left(\mathrm{N}_{1}\right) \mathrm{H}^{+}$ & $\operatorname{LP}\left(\mathrm{N}_{3}\right)$ & $\mathrm{BD}^{*}\left(\mathrm{P}-\mathrm{C}_{6}\right)$ & 9.3 \\
\hline $\mathrm{N}_{1}$-methyl-pta & $\operatorname{LP}\left(\mathrm{N}_{2}\right)$ & $\mathrm{BD}^{*}\left(\mathrm{C}_{1}-\mathrm{N}_{1}\right)$ & 17.2 \\
\hline $\mathrm{N}_{1}$-methyl-pta & $\operatorname{LP}\left(\mathrm{N}_{2}\right)$ & $\mathrm{BD}^{*}\left(\mathrm{C}_{3}-\mathrm{N}_{3}\right)$ & 9.5 \\
\hline $\mathrm{N}_{1}$-methyl-pta & $\operatorname{LP}\left(\mathrm{N}_{2}\right)$ & $\mathrm{BD}^{*}\left(\mathrm{P}-\mathrm{C}_{5}\right)$ & 9.1 \\
\hline $\mathrm{N}_{1}$-methyl-pta & $\operatorname{LP}\left(\mathrm{N}_{3}\right)$ & $\mathrm{BD}^{*}\left(\mathrm{C}_{2}-\mathrm{N}_{1}\right)$ & 17.2 \\
\hline $\mathrm{N}_{1}$-methyl-pta & $\operatorname{LP}\left(\mathrm{N}_{3}\right)$ & $\mathrm{BD}^{*}\left(\mathrm{C}_{3}-\mathrm{N}_{2}\right)$ & 9.5 \\
\hline $\mathrm{N}_{1}$-methyl-pta & $\operatorname{LP}\left(\mathrm{N}_{3}\right)$ & $\mathrm{BD}^{*}\left(\mathrm{P}-\mathrm{C}_{6}\right)$ & 9.1 \\
\hline fumarate-pta & $\operatorname{LP}\left(\mathrm{N}_{1}\right)$ & $\mathrm{BD}^{*}\left(\mathrm{C}_{1}-\mathrm{N}_{2}\right)$ & 9.75 \\
\hline fumarate-pta & $\operatorname{LP}\left(\mathrm{N}_{1}\right)$ & $\mathrm{BD}^{*}\left(\mathrm{C}_{2}-\mathrm{N}_{3}\right)$ & 9.8 \\
\hline fumarate-pta & $\operatorname{LP}\left(\mathrm{N}_{1}\right)$ & $\mathrm{BD}^{*}\left(\mathrm{P}-\mathrm{C}_{4}\right)$ & 9.0 \\
\hline fumarate-pta & $\operatorname{LP}\left(\mathrm{N}_{2}\right)$ & $\mathrm{BD} *\left(\mathrm{C}_{1}-\mathrm{N}_{1}\right)$ & 9.7 \\
\hline
\end{tabular}




\begin{tabular}{|c|c|c|c|}
\hline fumarate-pta & $\mathrm{LP}\left(\mathrm{N}_{2}\right)$ & $\mathrm{BD}^{*}\left(\mathrm{C}_{3}-\mathrm{N}_{3}\right)$ & 9.7 \\
\hline fumarate-pta & $\mathrm{LP}\left(\mathrm{N}_{2}\right)$ & $\mathrm{BD}^{*}\left(\mathrm{P}-\mathrm{C}_{5}\right)$ & 9.9 \\
\hline fumarate-pta & $\operatorname{LP}\left(\mathrm{N}_{3}\right)$ & $\mathrm{BD}^{*}\left(\mathrm{C}_{2}-\mathrm{N}_{1}\right)$ & 9.7 \\
\hline fumarate-pta & $\operatorname{LP}\left(\mathrm{N}_{3}\right)$ & $\mathrm{BD}^{*}\left(\mathrm{C}_{3}-\mathrm{N}_{2}\right)$ & 9.7 \\
\hline fumarate-pta & $\operatorname{LP}\left(\mathrm{N}_{3}\right)$ & $\mathrm{BD}^{*}\left(\mathrm{P}-\mathrm{C}_{6}\right)$ & 9.4 \\
\hline fumarate-pta & $\mathrm{LP}_{1}\left(\mathrm{O}_{1}\right)$ & $\mathrm{BD}^{*}\left(\mathrm{P}-\mathrm{C}_{4}\right)$ & 1.1 \\
\hline fumarate-pta & $\mathrm{LP}_{2}\left(\mathrm{O}_{1}\right)$ & $\mathrm{BD}^{*}\left(\mathrm{P}-\mathrm{C}_{4}\right)$ & 4.6 \\
\hline fumarate-ptaH ${ }^{+}$ & $\operatorname{LP}\left(\mathrm{N}_{2}\right)$ & $\mathrm{BD} *\left(\mathrm{C}_{1}-\mathrm{N}_{1}\right)$ & 16.0 \\
\hline fumarate- $\mathrm{ptaH}^{+}$ & $\mathrm{LP}\left(\mathrm{N}_{2}\right)$ & $\mathrm{BD}^{*}\left(\mathrm{C}_{3}-\mathrm{N}_{3}\right)$ & 9.5 \\
\hline fumarate- $\mathrm{ptaH}^{+}$ & $\mathrm{LP}\left(\mathrm{N}_{2}\right)$ & $\mathrm{BD}^{*}\left(\mathrm{P}-\mathrm{C}_{5}\right)$ & 9.8 \\
\hline fumarate- $\mathrm{ptaH}^{+}$ & $\operatorname{LP}\left(\mathrm{N}_{3}\right)$ & $\mathrm{BD}^{*}\left(\mathrm{C}_{2}-\mathrm{N}_{1}\right)$ & 16.1 \\
\hline fumarate- $\mathrm{ptaH}^{+}$ & $\operatorname{LP}\left(\mathrm{N}_{3}\right)$ & $\mathrm{BD} *\left(\mathrm{C}_{3}-\mathrm{N}_{2}\right)$ & 9.5 \\
\hline fumarate- $\mathrm{ptaH}^{+}$ & $\operatorname{LP}\left(\mathrm{N}_{3}\right)$ & $\mathrm{BD}^{*}\left(\mathrm{P}-\mathrm{C}_{6}\right)$ & 8.8 \\
\hline fumarate- $\mathrm{ptaH}^{+}$ & $\mathrm{LP}_{1}\left(\mathrm{O}_{1}\right)$ & $\mathrm{BD}^{*}\left(\mathrm{P}-\mathrm{C}_{4}\right)$ & 2.5 \\
\hline fumarate- $\mathrm{ptaH}^{+}$ & $\mathrm{LP}_{2}\left(\mathrm{O}_{1}\right)$ & $\mathrm{BD}^{*}\left(\mathrm{P}-\mathrm{C}_{4}\right)$ & 11.3 \\
\hline
\end{tabular}

$\mathrm{LP}=$ lone pair, $\mathrm{BD}^{*}=$ unoccupied bond

Reaction of pta with the dicarboxylic acids used in this study may also involve protonation (Equation 1):

$$
\mathrm{HO}_{2} \mathrm{C}-\mathrm{CH}=\mathrm{CH}-\mathrm{CO}_{2} \mathrm{H}+\mathrm{pta} \rightleftharpoons \mathrm{HO}_{2} \mathrm{C}-\mathrm{CH}=\mathrm{CH}-\mathrm{CO}_{2}{ }^{-}+\mathrm{ptaH}^{+}
$$

The calculations showed that such a protonation is a disfavoured process and the reactant side of equilibrium (1) is more favourable by $20.5 \mathrm{~kJ} / \mathrm{mol}$ for maleic acid and by $27.6 \mathrm{~kJ} / \mathrm{mol}$ for fumaric acid.

The formation of phosphonium salts is a two step process. In the first step one of the carbon atoms of the ethylene unit of the unsaturated acid interacts with the pta molecule yielding a carbanionic intermediate. In the second step this intermediate is protonated on the other carbon atom of the ethylene unit. The calculated structures of the intermediates formed from fumarate with pta or $\mathrm{ptaH}^{+}$are shown on Figure 6. 

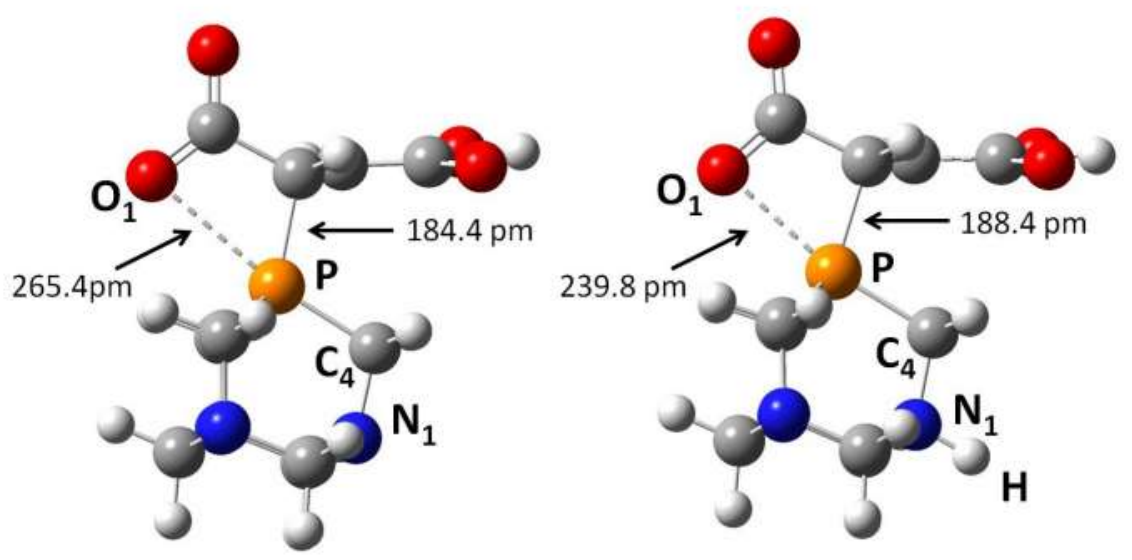

Figure 6. Structures of the intermediates of the fumarate-pta (left) and the fumarate-ptaH ${ }^{+}$ reactions (right).

The feasibility of phosphonium salt formation in reactions of pta, $\mathrm{ptaH}^{+}$and N-methyl-pta with several unsaturated dicarboxylic acids or their monoanions was assessed by calculation of relative Gibbs free energies of the intermediates formed in the first step of the reactions. The results, together with the relevant $d_{P-C}$ and $d_{P-O}$ distances are shown in Table 4 (see also Figure 6).

Table 4. Calculated relative Gibbs free energies, $\mathrm{d}_{\mathrm{P}-\mathrm{C}}$ and $\mathrm{d}_{\mathrm{P}-\mathrm{O}}$ distances of the intermediates formed in the pta/ptaH - unsaturated dicarbocylic acid/dicarboxylate systems.

\begin{tabular}{|c|c|c|c|c|}
\hline Entry & Reactants & $\begin{array}{c}\Delta \mathrm{G} \\
(\mathrm{kJ} / \mathrm{mol})\end{array}$ & $\begin{array}{c}\mathrm{d}_{\mathrm{P}-\mathrm{C}} \\
(\mathrm{pm})\end{array}$ & $\begin{array}{c}\mathrm{d}_{\mathrm{P}-\mathrm{O}} \\
(\mathrm{pm})\end{array}$ \\
\hline 1 & pta + fumarate & 75.8 & 184.4 & 265.4 \\
\hline 2 & $\mathrm{pta}+$ maleate & 71.6 & 184.3 & 262.9 \\
\hline 3 & $\mathrm{pta}+$ fumaric acid & 83.0 & 184.8 & 288.4 \\
\hline 4 & pta + maleic acid & 63.9 & 185.3 & 283.3 \\
\hline 5 & ptaH + fumarate & 98.8 & 188.4 & 239.8 \\
\hline 6 & ptaH + maleate & 101.9 & 187.0 & 231.4 \\
\hline 7 & ptaH + fumaric acid & 124.6 & 189.2 & 275.4 \\
\hline 8 & ptaH + maleic acid & 124.5 & 186.3 & 279.1 \\
\hline 9 & pta-Me + fumarate & 102.5 & 188.3 & 239.8 \\
\hline 10 & pta-Me + maleate & 94.4 & 186.8 & 231.3 \\
\hline 11 & pta-Me + fumaric acid & 130.7 & 190.6 & 273.5 \\
\hline 12 & pta-Me + maleic acid & 107.2 & 189.2 & 270.7 \\
\hline 13 & pta + mesaconate & 90.2 & 186.4 & 260.8 \\
\hline 14 & pta + citraconate & 83.8 & 196.5 & 259.2 \\
\hline
\end{tabular}


The data in Table 4 show unambigously that both protonation and methylation of pta result in loss of reactivity towards the acid monoanions (entries $1,5,9$ or 2,6,10). Protonation of the carboxylate anion (i.e. reaction with undissociated carboxylic acid) is similarly less favourable (entries 1 vs $3 ; 5$ vs 7; 9 vs 11) and the intermediates are strongly destabilized in the reaction of undissociated acids with protonated or N-methylated pta (ptaH and pta-Me, respectively) as shown, for example, by entries 7 and 11 . The $\Delta \mathrm{G}$ values of Table 2 are in agreement with the experimentally observed higher reactivity of maleic acid, in comparison to that of fumaric acid. The $\mathrm{d}_{\mathrm{P}-\mathrm{C}}$ distances increase with the increasing relative Gibbs free energies reflecting the weaker interactions between the pta phosphorus and the appropriate carbon atoms of the unsaturated acids. Conversely, the increased charge on pta brought about by $\mathrm{N}$-protonation or $\mathrm{N}$-methylation results in the decrease of the $\mathrm{d}_{\mathrm{P}-\mathrm{O}}$ distances (e.g. entries 1 vs 5 or 2 vs 6 ) due to the donor-acceptor interaction of the antibonding orbital of the $\mathrm{P}_{-} \mathrm{C}_{4}$ bond with the lone pair of one of the carboxylate oxygens. This effect is largely eliminated by the protonation of the carboxylate oxygen (entries 5 vs 7 or 6 vs 8 ) and in the cases of $\mathrm{ptaH}+$ fumaric acid or $\mathrm{ptaH}+$ maleic acid both the $\mathrm{d}_{\mathrm{P}-\mathrm{C}}$ and the $\mathrm{d}_{\mathrm{P}-\mathrm{O}}$ values are even larger than in the pta + fumarate or pta + maleate systems (Table 4$)$.

Reactions of half-deprotonated methylmaleic (citraconic) and methylfumaric (mesaconic) acids yield energetically less favourable intermediates than maleate and fumarate (entries 13, 14 vs 1,2). The major reason for this destabilization is that in the mesaconate and citraconate monoanions the carbon atom next to the methyl group (i.e. one $\mathrm{C}$ atom of the $\mathrm{C}=\mathrm{C}$ bond) is more positively charged than in fumarate or maleate. In addition to this unfavourable electronic effect the steric requirement of the methyl group should also be considered. However, in the citraconate monoanion the carboxylate group closer to the methyl is perpendicular to the plane defined by the $\mathrm{C}=\mathrm{C}$ bond (Figure 7 ) which may result in stronger $\mathrm{P}-\mathrm{O}$ interaction facilitating the formation of the intermediate. In the case of mesaconate, however, such an out-of-plane torsion of the carboxylate group is not significant (Figure 7) therefore this carboxylate is not able to act as an anchor during the formation of the intermediate. 


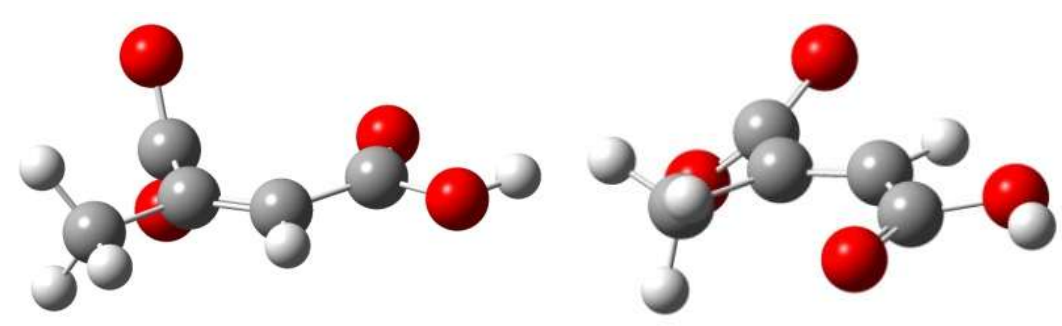

Figure 7. Structures of the citraconate (left) and mesaconate (right) monoanions.

These results of the calculations agree well with the experimental findings in that citraconic acid reacts with pta much slower than maleic or fumaric acid (44\% conversion in 9 months) while mesaconic acid shows hardly any reactivity ( $8.5 \%$ conversion in 9 months).

The second step of phosphonium salt formation, that is the protonation of the intermediate compound, may happen from the solvent molecules either directly or by a carboxylate-assisted proton transfer. The activation barriers of this step were found in the wide range of 40-100 kJ/mol, largely depending on the orientation of the solvent molecules. As an example, data for one of the possible transition states is presented as Supporting Information (Table S1).

\section{Conclusion}

Although in anhydrous solvents the reaction of $\mathrm{PPh}_{3}$ with $\alpha, \beta$-unsaturated carboxylic acids is facilitated by addition of trifluoroacetic acid, and sulfonated triphenylphosphanes ( $m$ tppms, $m$ tppts) also react readily with activated olefins in strongly acidic aqueous solutions, under the same conditions no formation of phosphonium salts was observed when $m$ tppms or $m$ tppts was replaced by 1,3,5-triaza-7-phosphaadamantane (pta). In contrast to these earlier observations pta was shown to form phosphonium salts (phosphonium alkanoate zwitterions) with unsaturated dicarboxylic acids in aqueous solutions in the absence of strong acid additives. Although the reactions were slow, high yield of the corresponding phosphonium salt (1) could be obtained in reaction of pta with maleic acid or fumaric acid. Methylmaleic (citraconic) and methylfumaric (mesaconic) acids reacted sluggishly to yield 2. Single crystal $\mathrm{X}$-ray studies revealed an extensive H-bond network within the crystals of $\mathbf{1}$ and $\mathbf{2}$. According to DFT calculations the most favourable route to the intermediate carbanionic adduct of the starting compounds is the reaction of unprotonated pta and a half-deprotonated alkenedioic acid, and this finding explains the lack of phosphonium salt formation in strongly acidic aqueous media observed previously. The calculations also revealed that during the reaction of 
pta with the alkenedioate monoanion, one of the carboxylate oxygens interacts with the partially positive phosphorus atom and thereby facilititates the formation of the intermediate carbanion. Due to the favourable structural features of citraconate, such an anchoring effect is more likely with this substrate than in the case of mesaconate and this is reflected in the reactivity of the two isomeric compounds.

\section{Crystal structure data}

CCDC 1042698 (1) and CCDC 1042699 (2) contain the supplementary crystallographic data for this paper. These data can be obtained free of charge from the Cambridge Crystallographic Data Centre via www.ccdc.cam.ac.uk/data_request/cif.

\section{Supplementary data}

Formulae of $m$ tppms, $m$ tppms, pta, numbering scheme of [P-methyl-pta $]^{+}$and P-(2carboxyethyl)-pta, comparison of the structures of $\mathbf{2}$ and [P-methyl-pta] ${ }^{+}$, and transition state data for the water-assisted proton transfer of the fumaric acid - pta system.

\section{Acknowledgements}

This research was supported by the European Union and the State of Hungary, co-financed by the European Social Fund in the framework of TÁMOP-4.2.4.A/ 2-11/1-2012-0001 'National Excellence Program' through a grant to A.U. Thanks are due to the Hungarian Research Fund (OTKA K101372) for financial support. The authors thank Dr. Attila Bényei for his invaluable contributions to the X-ray structure determinations. The participation of Henrietta Molnár in the initial experiments is gratefully acknowledged. The research was supported by the EU and co-financed by the European Social Fund under the project ENVIKUT (TÁMOP4.2.2.A-11/1/KONV-2012-0043). 


\section{References}

[1] Byrne PA, Gilheany D (2013) Chem Soc Rev 42: 6670-6696

[2] Kolodiazhnyi O. I. (1999) Phosphorus ylides. Chemistry and applications in organic synthesis, Wiley-VCH, Weinheim, Germany

[3] Shi M, Xu B (2002) J Org Chem 67: 294-297

[4] Wu J, Zhang D, Wei S (2005) Synth Commun 35: 1213-1222

[5] El-Batta A, Jiang C, Zhao W, Anness R, Cooksy AL, Bergdahl M (2007) J Org Chem 72: 5244-5259

[6] Islami MR, Yavari I, Tikdan AM, Ebrahimi L, Razee S, Bijanzadeh HR (2002) Russian Chem Bull 51: 2244-2247

[7] Li CJ, Chan TH (2007) Comprehensive Organic Reactions in Aqueous Media, $2^{\text {nd }}$ ed, John Wiley \& Sons Inc, Hoboken NJ, USA

[8] Kim JN, Lee KA, Kim HS, Im YJ (2001) Bull Korean Chem Soc 22: 351-352

[9] Balema VP, Wiench JW, Pruski M, Pecharsky VK (2002) Chem Commun: 724-725 [10] Joó F (2001) Aqueous Organometallic Catalysis, Kluwer, Dordrecht, The Netherlands [11] Larpent C, Patin H (1988) Tetrahedron 44: 6107-6118

[12] Darensbourg DJ, Joó F, Kathó Á, Stafford JNW, Bényei A (1994) Inorg Chem 33: 175177

[13] Bényei A, Stafford JNW, Kathó Á, Darensbourg DJ, Joó F (1993) J Mol Catal 84: 157163

[14] Phillips DA, Gonsalvi L, Romerosa A, Vizza F, Peruzzini M (2004) Coord Chem Rev 248: 955-993,

[15] Bravo J, Bolano S, Gonsalvi L, Peruzzini M (2010) Coord Chem Rev 254: 555-607

[16] Scolaro C, Bergamo A, Brescacin L, Delfino R, Cocchietto M, Laurenczy G, Geldbach TJ, Sava G, Dyson PJ (2005) J Med Chem 48: 4161-4171

[17] Darensbourg MY, Daigle DJ (1975) Inorg Chem 14: 1217-1218

[18] Daigle DJ, Pepperman AB, Vail SL 1974) J Heterocyclic Chem 11: 407-408

[19] Daigle DJ (1998) Inorg Synth 32: 40-41

[20] Fisher KJ, Alyea EC, Shahnazarian N (1990) Phosphorous Sulfur Silicon 48: 37-40

[21] Joó F, Nádasdi L, Bényei A, Csiba P, Kathó Á (1995) in Aqueous Organometallic

Chemistry and Catalysis (I. T. Horváth, F. Joó, eds) NATO ASI Series, 3. High Technology, Vol. 5, pp. 23-32, Kluwer, Dordrecht, The Netherlands

[22] Darensbourg DJ, Joo F, Kannisto M, Katho A, Reibenspies JH (1992)

Organometallics 11: 1990-1993 
[23] Assmann B, Angermaier K, Paul M, Riede J, Schmidbaur H (1995) Chem Ber 128: $891-900$

[24] He Z, Tang X, Chen Y, He Z (2006) Adv Synth Catal 348: 413-417

[25] Tang X, Zhang B, He Z, Gao R, He Z (2007) Adv Synth Catal 349: 2007-2017

[26] Romerosa A, Campos-Malpartida T, Lidrissi C, Saoud M, Serrano-Ruiz M, Peruzzini M, Garrido-Cárdenas JA, García-Maroto F (2006) Inorg Chem 45: 1289-1298

[27] Altomare A, Cascarano G, Giacovazzo C, Guagliardi A (1993) J Appl Crystallogr 26: $343-350$

[28] Sheldrick GM (2008) ActaCryst. A64: 112-122

[29] Farrugia LJ (1999) J Appl Cryst 32: 837-838

[30] Zhao Y, Truhlar D (2008) Theor Chem Acc 120: 215-241

[31] McLean AD, Chandler GS (1980) J Chem Phys 72: 5639-5648

[32] Frisch MJ, Trucks GW, Schlegel HB, Scuseria GE, Robb MA, Cheeseman JR, Scalmani G, Barone V, Mennucci B, Petersson GA, Nakatsuji H, Caricato M, Li X, Hratchian HP, Izmaylov AF, Bloino J, Zheng G, Sonnenberg JL, Hada M, Ehara M, Toyota K, Fukuda R, Hasegawa J, Ishida M, Nakajima T, Honda Y, Kitao O, Nakai H, Vreven T, Montgomery JA, Peralta JE, Ogliaro F, Bearpark M, Heyd JJ, Brothers E, Kudin KN, Staroverov VN, Kobayashi R, Normand J, Raghavachari K, Rendell A, Burant JC, Iyengar SS, Tomasi S, Cossi M, Rega N, Millam NJ, Klene M, Knox JE, Cross JB, Bakken V, Adamo C, Jaramillo J, Gomperts R, Stratmann RE, Yazyev O, Austin AJ, Cammi R, Pomelli C, Ochterski JW, Martin RL, Morokuma K, Zakrzewski WG, Voth GA, Salvador P, Dannenberg JJ, Dapprich S, Daniels AD, Farkas Ö, Foresman JB, Ortiz JV, Cioslowski J, Fox DJ (2009) Gaussian 09, Rev. A. 1, Gaussian, Inc., Wallingford CT

[33] Tomasi J, Mennucci B, Cammi R (2005) Chem Rev 105: 2999-3093

[34] Scalmani G, Frisch GJ (2010) J Chem Phys 132: 114110-114115

[35] Peng C, Schlegel HB (1994) Isr J Chem 33: 449-454

[36] Peng C, Ayala PY, Schlegel HB, Frisch MJ (1996) J Comp Chem 17: 49-56

[37] Fluck E, Forster J-E, Weidlein J, Hadicke E (1977) Z Naturforsch B: Chem Sci 32: 499501

[38] Shahat M (1952) Acta Cryst 5: 763-768 